\title{
A CONTRIBUTION TO KNOWLEDGE OF FRESHWATER MOLLUSCS (MOLLUSCA) OF THE KRKA RIVER IN THE KRKA NATIONAL PARK (CROATIA)
}

\section{LUBOŠ BERAN}

Nature Conservation Agency of the Czech Republic, Regional Office Kokořínsko - Máchův kraj Protected Landscape Area Administration, Česká 149, CZ-276 01 Mělník, Czech Republic (e-mail: lubos.beran@nature.cz)

Beran, L.: A contribution to knowledge of freshwater molluscs (Mollusca) of the Krka River in the Krka National Park (Croatia). Nat. Croat., Vol. 25, No. 2., 295-304, 2016, Zagreb.

The results of a malacological survey of the Krka River between Knin and Skradinski buk waterfalls in the Krka National Park are presented. The molluscan assemblages of this karstic river were studied from 2009 to 2013. Altogether, 27 species of freshwater molluscs (19 gastropods, 8 bivalves) were found at 14 sites. Theodoxus fluviatilis, Bithynia tentaculata, Valvata piscinalis, Stagnicola fuscus, Physa fontinalis and Anodonta anatina were dominant at most of the sites. A population of the endangered Anisus vorticulus was found upstream of the Skradinski buk waterfalls and in Visovac Lake.

Key words: Mollusca, Gastropoda, Bivalvia, Anisus vorticulus, faunistic, Krka, river, Croatia

Beran, L.: Doprinos poznavanju faune slatkovodnih mekušaca (Mollusca) rijeke Krke u Nacionalnom parku Krka (Hrvatska). Nat. Croat., Vol. 25, No. 2., 295-304, 2016, Zagreb.

U radu se prezentiraju rezultati malakološkog istraživanja rijeke Krke između Knina i slapova Skradinski buk u NP Krka. Zajednice mekušaca ove krške rijeke istraživane su od 2009. do 2013. godine. Ukupno je na 14 lokaliteta nađeno 27 vrsta slatkovodnih mekušaca (19 puževa, 8 školjkaša). Theodoxus fluviatilis, Bithynia tentaculata, Valvata piscinalis, Stagnicola fuscus, Physa fontinalis i Anodonta anatina su na većini lokaliteta bili dominantni. Populacija ugrožene vrste Anisus vorticulus nađena je uzvodno od slapova Skradinski buk i u jezeru Visovac.

Ključne riječi: Mollusca, Gastropoda, Bivalvia, Anisus vorticulus, faunistika, Krka, rijeka, Hrvatska

\section{INTRODUCTION}

The Krka is a well known river in Croatia's Dalmatia region, noted for its numerous waterfalls. It is $73 \mathrm{~km}$ long and its basin covers an area of more than $2000 \mathrm{~km}^{2}$. An area of 109 square $\mathrm{km}$ encompassing part of the basin and course of the Krka River (from 2 km downstream of Knin to Skradin) was declared to be the Krka National Park in 1985. Freshwater molluscs of this river have not been investigated sufficiently. Findings of small hydrobiids living primarily in springs and underground waters in surroundings exist. Shells of these hydrobiids can occasionally also be found in sediments of the Krka River. These records are concentrated at Skradinski Buk waterfalls and its surroundings. Bole (1992) described Lanzaia skradinensis (Bole, 1992) from two springs downstream of the power plant station at Skradinski buk while empty shells of Kerkia jadertina (Kuščer, 1933) were found under Skradinski buk waterfalls (BERAN et al., 2014). There are however insufficient data concerning the occurrence of freshwater gastropods and bivalves inhabiting the Krka River. GLöER et al. (2007) described Pseudobythinia kirka (Glöer, Al- 
brecht \& Wilke, 2007) from the Skradinski buk waterfalls. BERAN (2009) found Anisus vorticulus there. This find was the first record of this endangered snail in the western part of Croatia belonging to the Adriatic Sea drainage area. Molluscan assemblages of this river were recently also studied by VučKović (2013). This author recorded 29 species of aquatic molluscs (20 freshwater snails, 1 brackish snail, 8 freshwater bivalves).

The main aim of this research was to provide an inventory of freshwater molluscs living in the Krka River and adjacent freshwater habitats (e. g. pools), examine their population densities, as well as the occurrence of endangered and non-native molluscs.

\section{MATERIAL AND METHODS}

Material was collected during the author's field research in summer 2009-2013. Freshwater molluscs of the Krka River and adjacent habitats (e. g. pools) between Knin and Skradinski buk waterfalls were studied. The main sampling method for aquatic molluscs used in the current research was washing vegetation or sediments using a metal sieve (diameter $20 \mathrm{~cm}, 0.8 \mathrm{~mm}$ mesh) combined with collection by hand, searching stone,wood and artificial material (e.g. plastic bags and bottles) surfaces. Diving (snorkelling) in shallow parts (ca to $3 \mathrm{~m}$ deep) was also used.

Freshwater molluscs were determined using shell characteristics or dissected and then identified using their copulatory organs if identification based only on shells was impossible. Specimens for dissection were killed in hot water and then fixed in $70 \%$ ethanol. Selected material of shells and killed specimens in $70 \%$ ethanol is deposited in the author's collection.

\section{SURVEY OF INVESTIGATED SITES}

Data in the list are as follows: site number, geographical co-ordinates (http://itouchmap.com), name of the nearest settlement, description of the site, date of investigation. Sites are depicted in Fig. 1.

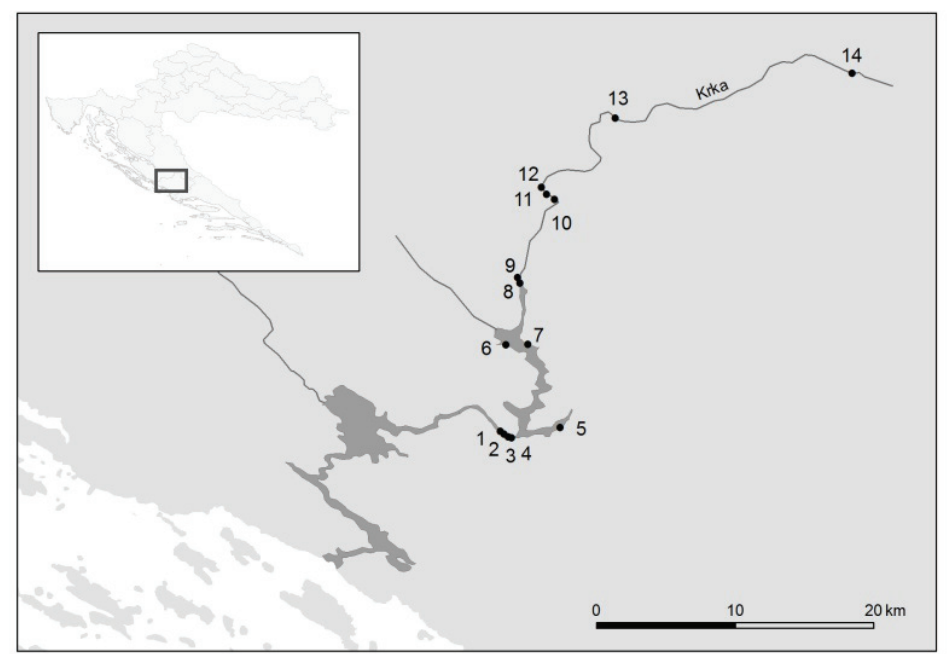

Fig. 1. The map of the Krka River with sites under study. Orig. H. Kaňková. 
$1-43^{\circ} 48^{\prime} 20^{\prime \prime} \mathrm{N}, 15^{\circ} 57^{\prime} 46^{\prime \prime} \mathrm{E}$, Lozovac, the Krka River downstream of Skradinski buk waterfalls, 1.8.2012;

$2-43^{\circ} 48^{\prime} 13^{\prime \prime} \mathrm{N}, 15^{\circ} 57^{\prime} 54^{\prime \prime} \mathrm{E}$, Lozovac, the Krka River along the paths by Skradinski buk waterfalls, a) 11.8.2009, b) 10.7.2010;

$3-43^{\circ} 48^{\prime} 08^{\prime \prime} \mathrm{N}, 15^{\circ} 58^{\prime} 00^{\prime \prime} \mathrm{E}$, Lozovac, small lakes (pools) of the Krka River at the bus stop nearSkradinski buk waterfalls, a) 11.8.2009, b) 10.7.2010;

$4-43^{\circ} 48^{\prime} 07^{\prime \prime} \mathrm{N}, 15^{\circ} 58^{\prime} 04^{\prime \prime} \mathrm{E}$, Lozovac, Visovac Lake upstream of Skradinki buk waterfalls, 1.8.2012;

$5-43^{\circ} 48^{\prime} 29^{\prime \prime} \mathrm{N}, 16^{\circ} 00^{\prime} 06^{\prime \prime} \mathrm{E}$, Goriš, left bank of Visovac Lake in the bay of the inflow of the Čikola River, 13.8.2013;

$6-43^{\circ} 51^{\prime} 43^{\prime \prime} \mathrm{N}, 15^{\circ} 57^{\prime} 59^{\prime \prime} \mathrm{E}$, Visovac, right bank of Visovac Lake opposite Visovac Monastery, a) 6.7.2012, b) 13.8.2013;

$7-43^{\circ} 51^{\prime} 44^{\prime \prime} \mathrm{N}, 15^{\circ} 58^{\prime} 50^{\prime \prime} \mathrm{E}$, Visovac, left bank of Visovac Lake Visovac Monastery, 10.7.2010;

$8-43^{\circ} 54^{\prime} 07^{\prime \prime} \mathrm{N}, 1^{\circ} 58^{\prime} 32^{\prime \prime} \mathrm{E}$, Laškovica, Krka River downstream of Roški slap in Visovac Lake, 10.7.2010 (Fig. 2 and 3);

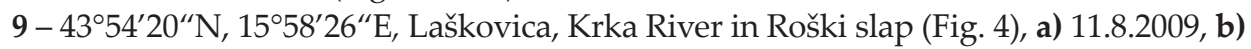
10.7.2010;

$10-43^{\circ} 57^{\prime} 23^{\prime \prime} \mathrm{N}, 15^{\circ} 59^{\prime} 53^{\prime \prime} \mathrm{E}$, Kistanje, Krka River 300 m downstream of Krka Monastery, 1.7.2012;

$11-43^{\circ} 57^{\prime} 33^{\prime \prime} \mathrm{N}, 15^{\circ} 59^{\prime} 31^{\prime \prime} \mathrm{E}$, Kistanje, the eastern bank of the extensive pool near Krka Monastery, 1.7.2012;

$12-43^{\circ} 57^{\prime} 41^{\prime \prime} \mathrm{N}, 15^{\circ} 59^{\prime} 07^{\prime \prime} \mathrm{E}$, Kistanje, the northwestern bank of the extensive pool near Krka Monastery (Fig. 5), 1.7.2012;

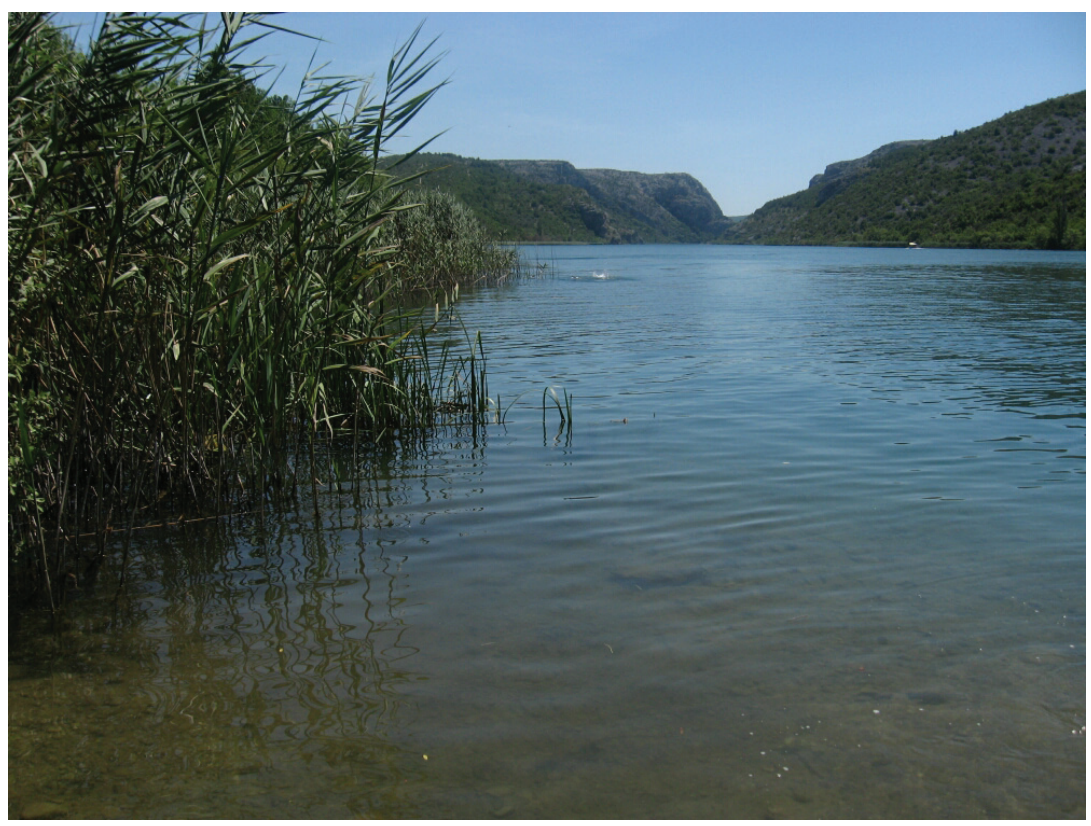

Fig. 2. The Krka River downstream of the Roški slap in Visovac Lake (site No. 8). All photos by author. 


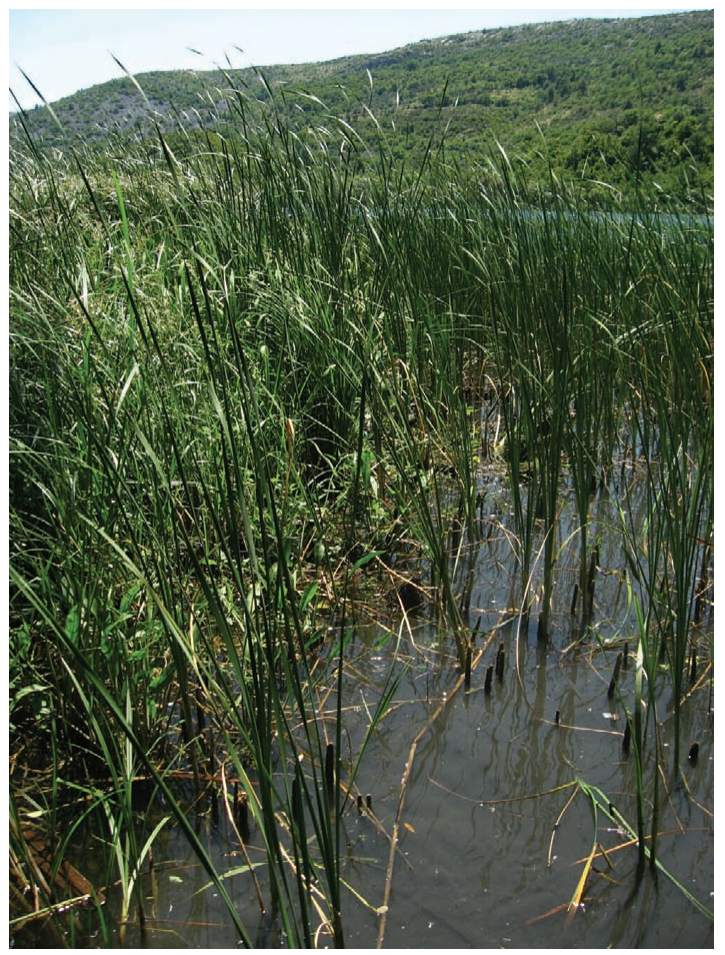

Fig. 3. A detail of a place in which A. vorticulus occurs (site No. 8).

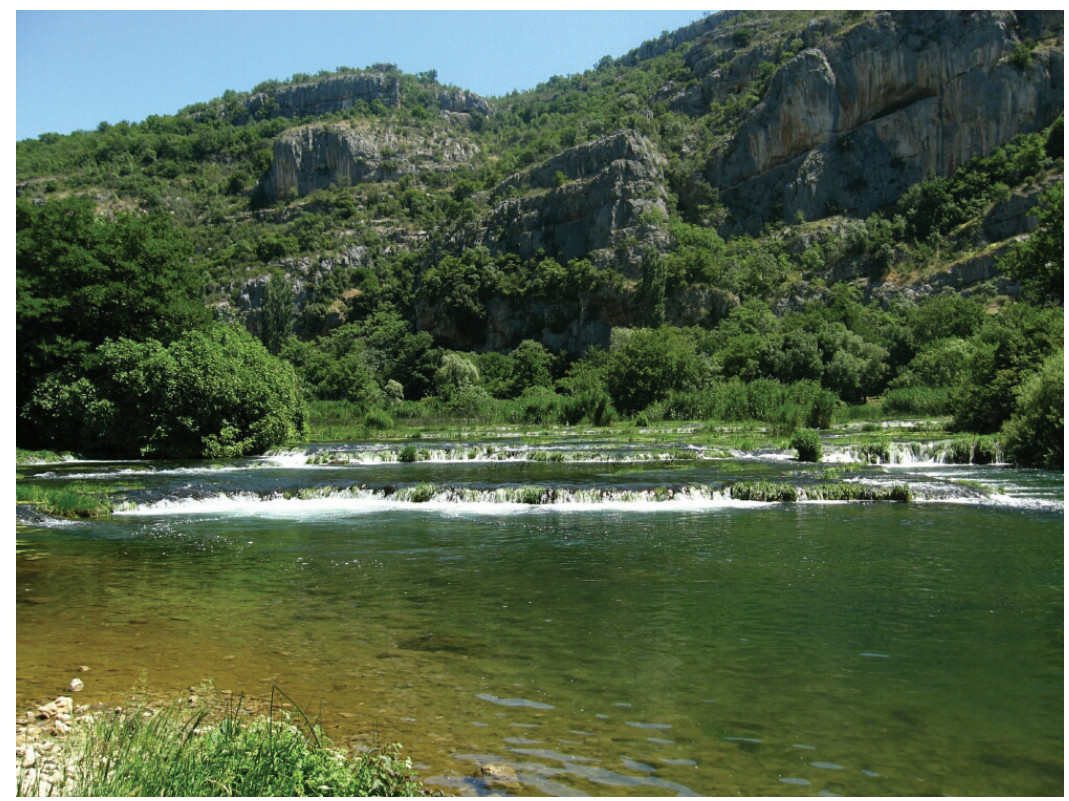

Fig. 4. The Krka River at Roški slap (site No. 9). 


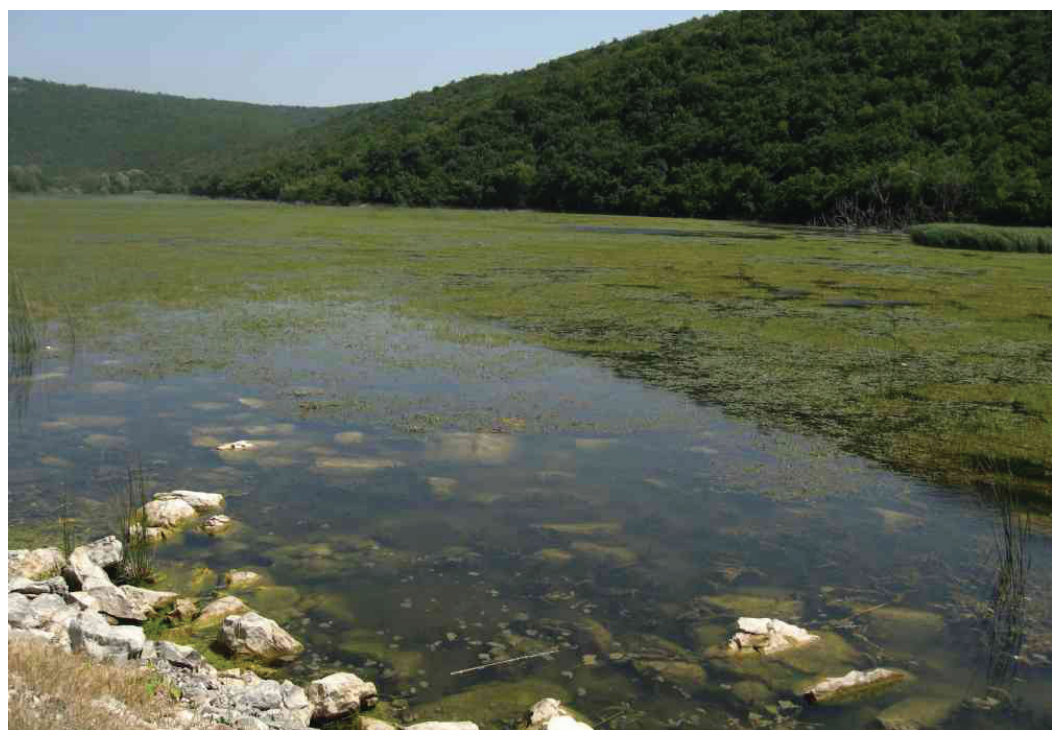

Fig. 5. The extensive pool near Krka Monastery (site No. 12).

$13-44^{\circ} 00^{\prime} 33^{\prime \prime} \mathrm{N}, 16^{\circ} 02^{\prime} 15^{\prime \prime} \mathrm{E}$, Puljane, Krka River in Brljansko jezero near a bridge of a road, a) 11.8.2009, b) 25.8.2011;

$14-44^{\circ} 01^{\prime} 55^{\prime \prime} \mathrm{N}, 16^{\circ} 11^{\prime} 25^{\prime \prime} \mathrm{E}, \mathrm{Knin}, \mathrm{Krka}$ River near the bridge on the Knin-Drniš road, 25.8.2011.

\section{RESULTS}

Altogether 27 species of freshwater molluscs (19 gastropods, 8 bivalves) were found in the Krka River and adjacent habitats in the Krka NP during the investigation period. A list of molluscs found at particular sites and an estimation of the density of their populations are shown in Tab.1. The number of species found at particular sites varied from 4 to 17. Theodoxus fluviatilis, Bithynia tentaculata, Valvata piscinalis, Stagnicola fuscus, Physa fontinalis and Anodonta anatina were dominant at most of the sites while Emmericia patula, Valvata cristata, Galba truncatula, Physa acuta, Planorbis planorbis, Gyraulus albus, Hippeutis complanatus, Musculium lacustre, Pisidium milium, Pisidium personatum were recorded at only one to three sites. Most of the recorded molluscs belong to common species in this part of Croatia. Unio mancus is listed in the IUCN Red List in the category Near Threatened (Lopes-Lima \& SEDdon, 2014). This species is among the most common bivalves in the lower stretch of the Krka River. Anisus vorticulus, an endangered species listed in the EU Habitat Directive (see Discussion) and a Data Deficient species according to IUCN Red List (VAN Damme, 2012), was found at 6 sites (Figs. 2 and 3). A population of this gastropod inhabits Visovac Lake and pools upstream of the Skradinki buk waterfalls. Upstream of Roški slap, this species was not found. The highest densities were recorded at sites No. 3, 4 and 6 . The population density of this species varied from a few specimens to over 80 ind. $/ \mathrm{m}^{2}$.

On the other hand only one non-native species, Physa acuta, was found in the extensive pool near Krka Monastery (Fig. 5). 


\begin{tabular}{|c|c|c|c|c|c|c|c|c|c|c|c|c|c|c|c|c|c|c|c|c|c|c|c|c|c|c|}
\hline & 으. & 10 & $\cong$ & 10 & $\infty$. & $-\rightarrow$ & 0 & $\infty$. & $-\rightarrow$ & $\stackrel{M}{2}$ & $\infty 1$ & $\Lambda$. & -9 & L & 6 & $N$ & $a$ & $m$ & $\infty$ & $\approx$ & - & $-L$ & 100 & $\sigma-$ & $H$ & \\
\hline \pm & & & & $\begin{array}{l}\stackrel{x}{x} \\
\text { x }\end{array}$ & $\begin{array}{l}\underset{x}{x} \\
\text { x }\end{array}$ & & & 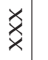 & & & & & yx & k. & & $x$ & $\times$ & & & & & & $\stackrel{x}{x}$ & $\stackrel{x}{\times}$ & & $\infty$ \\
\hline ल) & $\times$ & & $\begin{array}{l}\vec{x} \\
x \\
x\end{array}$ & $\times$ & $\begin{array}{l}\underset{x}{x} \\
\end{array}$ & & 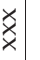 & & $\times$ & $\stackrel{x}{x}$ & & 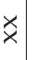 & $x$ & $k$ & & $\stackrel{x}{x}$ & $\stackrel{x}{x}$ & & & $\times$ & & & $\times$ & $\times$ & & 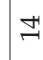 \\
\hline 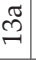 & & & $\begin{array}{l}x \\
x \\
x\end{array}$ & & $\begin{array}{l}x \\
x \\
x\end{array}$ & & & & & 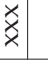 & & $\times$ & & & & & & & & & & & & & $x$ & 6 \\
\hline$\approx$ & & & & & & & & & & $\times$ & & $\times$ & $\begin{array}{l}\vec{x} \\
x \\
x\end{array}$ & & & & $\times$ & & & & & & & & & $\nabla$ \\
\hline$\exists$ & & & $x$ & & & & & $\times$ & & $\times$ & & $\times$ & & & & & $\stackrel{x}{x}$ & & & $\times$ & & & & & & 6 \\
\hline$\circ$ & & & $\stackrel{x}{x}$ & $\stackrel{x}{x}$ & $\stackrel{x}{x}$ & & \begin{tabular}{r|r}
$x$ \\
\\
\\
\end{tabular} & $\times$ & & $\times$ & & $\times$ & xx & k. & & & $x$ & & $\vec{x}$ & $\stackrel{x}{x}$ & $x$ & & $\times$ & $\times$ & $\rtimes$ & $\stackrel{20}{2}$ \\
\hline คి & $\begin{array}{l}x \\
x \\
x\end{array}$ & & $\begin{array}{l}x \\
x \\
x\end{array}$ & $\stackrel{x}{x}$ & & & & $\times$ & & $\times$ & & $\times$ & $\begin{array}{l}x \\
x \\
x\end{array}$ & & & & & & $\mid \begin{array}{l}x \\
x\end{array}$ & $\stackrel{x}{x}$ & & & & $\times$ & 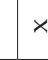 & 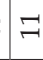 \\
\hline శూ & $\stackrel{x}{x}$ & & $\begin{array}{l}x \\
x \\
\times\end{array}$ & & & & & & & $\underset{x}{x}$ & & & $x$ & & & & & & $\mid \underset{x}{x}$ & & & & & $\times$ & & 6 \\
\hline$\infty$ & $\underset{x}{x}$ & & $\begin{array}{l}x \\
x\end{array}$ & $\times$ & & 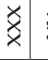 & $\stackrel{x}{x}$ & & & \begin{tabular}{l|l}
$\grave{x}$ & $\vdots$ \\
\end{tabular} & $\vec{x}$ & & $\begin{array}{l}x \\
x \\
x\end{array}$ & रे & $\times$ & & $x$ & $\times$ & $\times$ & $\ddot{x}$ & & $\times$ & $\times$ & $\times>$ & $\times$ & $\triangleq$ \\
\hline$\triangle$ & $\ddot{x}$ & $\stackrel{x}{\times}$ & $\stackrel{x}{x}$ & & & & $\stackrel{x}{\times}$ & $\begin{array}{l}x \\
x \\
x \\
\end{array}$ & & 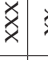 & $\underset{x}{x}$ & & $\vec{x}$ & x. & $\times$ & & $x$ & & $\times$ & $\stackrel{x}{x}$ & & & & & & $\cong$ \\
\hline 8 & $\times$ & $\times$ & $\vec{x}$ & & & & $\begin{array}{l}x \\
x \\
x \\
\end{array}$ & $\underset{x}{x}$ & & \begin{tabular}{l|l}
$\grave{x}$ & ,
\end{tabular} & $\times$ & $\times$ & y & x & $\stackrel{x}{x}$ & & $x$ & $\times$ & $x$ & $\stackrel{x}{\times}$ & & & $\times$ & $\times$ & & $\because$ \\
\hline శే & $\times$ & $\times$ & $\stackrel{x}{x}$ & & & & 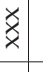 & $\stackrel{x}{x}$ & & 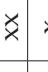 & $\times$ & $\times$ & x & x. & 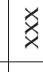 & & $x$ & $\times$ & $\times$ & $\vec{x}$ & & & $\times$ & $\underset{x}{x}$ & $\times$ & $\approx$ \\
\hline 10 & $\begin{array}{l}x \\
x \\
x \\
\end{array}$ & $\times$ & $\begin{array}{l}x \\
x \\
x \\
\end{array}$ & & & & $\begin{array}{l}x \\
x \\
x \\
\\
\end{array}$ & $\times$ & & 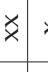 & $\times$ & $\times$ & & & $x$ & & $x$ & & & $\stackrel{x}{x}$ & & & & $\times$ & & $\cong$ \\
\hline 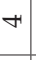 & $\underset{x}{x}$ & $\times$ & $\stackrel{x}{x}$ & & & & $\ddot{x}$ & $\stackrel{x}{x}$ & & 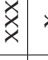 & $\times$ & & x & x & $\begin{array}{r}\text { x. } \\
\text { x. } \\
\end{array}$ & & & $\underset{x}{x}$ & $\begin{array}{l}x \\
x\end{array}$ & $\stackrel{x}{\times}$ & & & & $\times$ & & $\stackrel{M}{\longrightarrow}$ \\
\hline ले & $\begin{array}{l}x \\
x \\
x\end{array}$ & $\times$ & $\begin{array}{l}x \\
\times \\
\times\end{array}$ & & & & $\stackrel{x}{x}$ & & & $\times>$ & $\times$ & & $x$ & $x \times$ & $\begin{array}{l}x \\
x \\
x \\
\end{array}$ & & & & $x$ & $\times$ & & & & & & $\exists$ \\
\hline నే & $\underset{x}{x}$ & & $\begin{array}{l}x \\
x \\
x \\
\end{array}$ & & & & $\ddot{x}$ & & & $\times$ & & & $x$ & $x$ & $\stackrel{x}{x}$ & & & & $\times$ & $\times$ & & & & & & $\Lambda$ \\
\hline ते & $\underset{x}{x}$ & & $\begin{array}{l}x \\
x \\
x \\
\end{array}$ & & & & $\times$ & & & 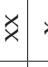 & $\times$ & & x. & 女x & & & & & $\stackrel{x}{x}$ & $\ddot{x}$ & & & & & & $\infty$ \\
\hline సూ & $\begin{array}{l}x \\
x \\
x\end{array}$ & & $\begin{array}{l}x \\
x \\
x \\
\end{array}$ & & & & $\underset{x}{x}$ & & & $\stackrel{x}{x}$ & & & $x$ & & & & & & \begin{tabular}{|l|l}
$x$ \\
$x$ \\
\end{tabular} & $\begin{array}{l}x \\
x \\
x\end{array}$ & & & & & & $\Lambda$ \\
\hline- & $\mid \begin{array}{l}x \\
x \\
x\end{array}$ & & $\begin{array}{l}x \\
x \\
x \\
\end{array}$ & & & & $\times$ & & & \begin{tabular}{l|l}
$\grave{x}$ & $>$ \\
\end{tabular} & $\times$ & & & & & & & & & $\times$ & & & & $\times$ & & 0 \\
\hline
\end{tabular}

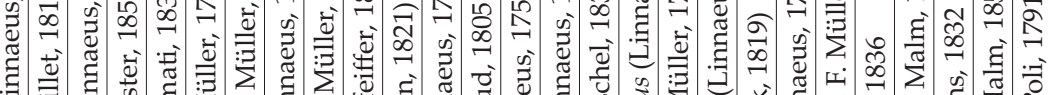

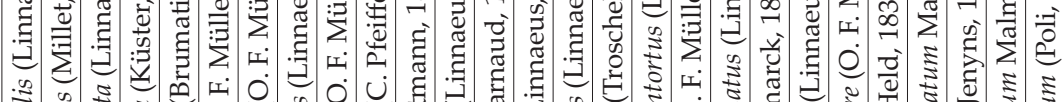




\section{DISCUSSION}

Rich molluscan assemblages inhabit the Krka River. The river is inhabited by both molluscs living in flowing waters (e. g. Theodoxus fluviatilis, Radomaniola curta, Emmericia patula, Radix ampla) and species preferring stagnant waters (e. g. Viviparus contectus, Stagnicola fuscus, Planorbis planorbis). The reason for this is the character of the river, where lakes (Visovac Lake) or stagnant parts are interrupted by waterfalls and fastflowing sections. The finding of the endangered gastropod A. vorticulus is the most important record due to the fact that populations of this snail have been declining in many European countries (VAN DAMmE, 2012). This dramatic change led the species being considered for inclusion in the EU Habitats Directive (a proposal of the Czech Republic during expansion, 2004) (Colling \& SCHRÖDER, 2006; ZetTLER \& WACHLIN, 2010). This species is listed in both Annex II (species of community interest requiring special areas for conservation) and Annex IV (strict protection) of the Directive.

The occurrence of $A$. vorticulus is also known from Mediterranean part of Croatia from the Vrana Lake Nature Park (Beran et al., 2013) but only a small population was found there in the dried Benča Lake. The population found in the Krka National Park is much more extensive and A. vorticulus is widespread in Visovac Lake and adjacent habitats. A. vorticulus was found in Visovac Lake for the first time in 2009 (BERAn 2009). Vučкоvić (2013) also found this species in Visovac Lake between Roški slap and Skradinski buk waterfalls. Due to the large size of this lake and the existence of suitable habitats there we can conclude that the population is the most extensive one known in the western part of Croatia belonging to the Adriatic Sea drainage area.

GLöEr et al. (2007) described Pseudobythinia kirka (Glöer, Albrecht \& Wilke, 2007) from Skradinski buk waterfalls. This species was sought during this research, and it was expected that this species would be detected. P. kirka was not found although more than 50 specimens of Bithyniidae from different habitats at the locus typicus and its surroundings were dissected and several specimens collected were also revised by P. Glöer. Only the common B. tentaculata was identified. During her research, VučKović (2013) also found only this common species.

The research was focused on the Krka River and adjacent habitats (e. g. pools). Springs, wells and underground waters were not studied. It is probable that research into them would detect the presence of other species especially small hydrobiids (see Introduction).

Only one non-native gastropod was found during this research. Physa acuta was not found in the main stream of the Krka River but only in a pool situated near Krka Monastery (site No. 12). This species probably inhabits suitable sites in the surroundings of the Krka National Park because it was found by the author in the small pool (Konjevratska lokva) near the cemetery in Konjevrate and also in the Butižnica River in Knin. The record of only one non-native mollusc showed that molluscan assemblages of the Krka River are only marginally attacked by non-native species.

VučKović (2013) who conducted her own research in 2012 and 2013 practically simultaneously with the author found very similar results. Nearly all the species were found by both authors. VučKović (2013) recorded two more species - brackish Adriohydrobia gagatinella (Küster, 1852) found below Skradinski buk waterfalls and the common Gyraulus crista (Linnaeus, 1758), recorded from one site. Brackish molluscs were not studied by L. Beran so it is the reason why A. gagatinella is not mentioned in this research and G. crista could be overlooked. VučKović (2013) mentioned Radix labiata (Rossmässler, 
Tab. 2. Comparison of molluscan assemblages of the Krka River and the Zrmanja River.

* in Beran (2011) mentioned as B. zermanica Radoman, 1973 and B. krupensis Radoman, 1973 but molecular data strongly suggest that both species are identical with B. kusceri (FALNIOwsKI \& BERAN, 2015).

** in BERAN (2011) mentioned only as Radix labiata but later R. ampla was identified in lower part of the Zrmanja River (L. Beran, unpublished records).

\begin{tabular}{|c|c|c|}
\hline Species/River & Krka & Zrmanja \\
\hline Theodoxus fluviatilis (Linnaeus, 1758) & $\mathrm{x}$ & $\mathrm{x}$ \\
\hline Viviparus contectus (Millet, 1813) & $\mathrm{x}$ & \\
\hline Bithynia tentaculata (Linnaeus, 1758) & $\mathrm{x}$ & $\mathrm{x}$ \\
\hline Sadleriana fluminensis (Küster, 1852) & & $\mathrm{x}$ \\
\hline Belgrandiella kusceri (A. J. Wagner, 1914)* & & $x$ \\
\hline Radomaniola curta (Küster, 1853) & $\mathrm{x}$ & $\mathrm{x}$ \\
\hline Dalmatinella fluviatilis Radoman, 1973 & & $\mathrm{x}$ \\
\hline Tanousia zrmanjae (Brusina, 1866) & & $x$ \\
\hline Pyrgula annulata (Linnaeus, 1767) & & $x$ \\
\hline Emmericia patula (Brumati, 1838) & $x$ & $\mathrm{x}$ \\
\hline Valvata cristata O. F. Müller, 1774 & $x$ & \\
\hline Valvata piscinalis (O. F. Müller, 1774) & $\mathrm{x}$ & $\mathrm{x}$ \\
\hline Acroloxus lacustris (Linnaeus, 1758) & $\mathrm{x}$ & $\mathrm{x}$ \\
\hline Galba truncatula (O. F. Müller, 1774) & $x$ & \\
\hline Stagnicola fuscus (C. Pfeiffer, 1821) & $\mathrm{x}$ & $\mathrm{x}$ \\
\hline Radix ampla (Hartmann, 1821)** & $\mathrm{x}$ & $\mathrm{x}$ \\
\hline Radix auricularia (Linnaeus, 1758) & $x$ & $x$ \\
\hline Radix labiata (Rossmäessler, 1835) & & $\mathrm{x}$ \\
\hline Physa fontinalis (Linnaeus, 1758) & $\mathrm{x}$ & \\
\hline Physa acuta (Draparnaud, 1805) & $x$ & \\
\hline Planorbis planorbis (Linnaeus, 1758) & $\mathrm{x}$ & $\mathrm{x}$ \\
\hline Planorbis carinatus (O. F. Müller, 1774) & & $\mathrm{x}$ \\
\hline Anisus vorticulus (Troschel, 1834) & $x$ & \\
\hline Bathyomphalus contortus (Linnaeus, 1758) & $\mathrm{x}$ & \\
\hline Gyraulus albus (O. F. Müller, 1774) & $\mathrm{x}$ & \\
\hline Hippeutis complanatus (Linnaeus, 1758) & $\mathrm{x}$ & $\mathrm{x}$ \\
\hline Ancylus fluviatilis (O. F. Müller, 1774) & & $\mathrm{x}$ \\
\hline Unio mancus (Lamarck, 1819) & $\mathrm{x}$ & $\mathrm{x}$ \\
\hline Anodonta anatina (Linnaeus, 1758) & $\mathrm{x}$ & $x$ \\
\hline Musculium lacustre (O. F. Müller, 1774) & $\mathrm{x}$ & \\
\hline Pisidium amnicum (O. F. Müller, 1774) & & $\mathrm{x}$ \\
\hline Pisidium milium Held, 1836 & $\mathrm{x}$ & \\
\hline Pisidium subtruncatum Malm, 1855 & $\mathrm{x}$ & $\mathrm{x}$ \\
\hline Pisidium nitidum Jenyns, 1832 & $\mathrm{x}$ & $\mathrm{x}$ \\
\hline Pisidium personatum Malm, 1855 & $\mathrm{x}$ & $\mathrm{x}$ \\
\hline Pisidium casertanum (Poli, 1791) & $\mathrm{x}$ & $\mathrm{x}$ \\
\hline Number of species & 27 & 26 \\
\hline
\end{tabular}


1835) while L. Beran referred to Radix ampla. The material of R. ampla was dissected by L. Beran and its identification was confirmed using DNA analysis (K. Schniebs, personal communication) so probably only $R$. ampla occurred in the Krka River. Some of the study sites of the two authors were situated in similar areas and their molluscan assemblages were often similar.

In comparison with the Zrmanja, the river situated to the north of the Krka River, which was studied recently (BERAN, 2011; L. Beran, unpublished records) the Krka River is significantly less occupied by small hydrobiids. No endemic species of this group was found in the Krka River. On the other hand gastropods preferring stagnant waters (Viviparus contectus, Anisus vorticulus, Bathyomphalus contortus) are more frequent there. The probable reason is the existence of the extensive Visovac Lake and other lakes and pools created by travertine cascades in this national park. Assemblages of bivalves are similar in the two rivers. The comparison of freshwater molluscs of these two rivers is given in Tab. 2.

\section{ACKNOWLEDGEMENTS}

I am obliged to Jasna Lajtner for help with permission for this research, which was enabled by the Ministry of Culture of Croatia. I would like to thank Helena Kaňková for preparing the map.

Received June 6, 2016

\section{REFERENCES}

Beran, L., 2009: The first record of Anisus vorticulus (Troschel, 1834) (Gastropoda: Planorbidae) in Croatia? - Malacologica Bohemoslovaca 8, 70. Online serial at <http://mollusca.sav.sk> 14-December-2009.

Beran, L., 2011: Non-marine molluscs (Mollusca: Gastropoda, Bivalvia) of the Zrmanja River and its tributaries (Croatia). - Nat. Croat. 20(2), 397-409.

Beran, L., Lajtner, J. \& Crnčan, P., 2013: Aquatic molluscan fauna (Mollusca: Gastropoda, Bivalvia) of Vrana Lake Nature Park (Croatia). - Nat. Croat. 22(1), 15-27.

Beran, L., Bodon, M. \& Cianfanelli, S., 2014: Revision of „Hauffenia jadertina“ Kusčer, 1933, and description of a new species from Pag Island, Croatia (Gastropoda: Hydrobiidae). - Journal of Conchology 41(5), 585-601.

Bole, J., 1992: Neue Arten der unterirdischen Schecken Westbalkans. Razprave IV. Razreda SAZU 33(1), 3-20.

Colling, M. \& Schröder, E., 2006: Anisus vorticulus (Troschel, 1834). In: Petersen B. \& Ellwanger G. (eds). Das europäische Schutzgebietssystem Natura 2000. Ökologie und Verbreitung von Arten der FFH Richtlinie in Deutschland, Band 3: Arten der EU Osterweiterung. Schrift. Landschaftspf. Naturschutz 69, 155-163.

Falniowski, A. \& Beran, L., 2015: Belgrandiella A. J. Wagner, 1928 (Caenogastropoda: Truncateloidea: Hydrobiidae): how many endemics? - Folia Malacologica 23(3), 187-191. http://dx.doi.org/10.12657/ folmal.023.015

Glöer, P., Albrecht, C. \& Wilke, T., 2007: Enigmatic distribution patterns of the Bithyniidae in the Balkan Region (Gastropoda: Rissoidea). - Mollusca 25(1), 13-22.

Lopes-Lima, M. \& Seddon, M.B., 2014: Unio mancus. The IUCN Red List of Threatened Species 2014: e.T22737A42466471. http://dx.doi.org/10.2305/IUCN.UK.2014-3.RLTS.T22737A42466471.en. Downloaded on 06 December 2016.

VAN Damme, D., 2012: Anisus vorticulus. The IUCN Red List of Threatened Species 2012: e.T155966A738056. http://dx.doi.org/10.2305/IUCN.UK.2012-1.RLTS.T155966A738056.en. Downloaded on 06 December 2016.

VučKović, N., 2013: Diversity of freshwater molluscs (Gastropoda, Bivalvia) of the Krka National Park. - Diploma thesis, Faculty of Science, Department of Biology, University of Zagreb, Croatia.

Zettler, M. L. \&WAchlin, V., 2010: Steckbriefe der in M-V vorkommenden Arten der Anhänge II und IV der FFH-Richtlinie: Anisus vorticulus (Troschel, 1834). Online at http://www.lung.mv-regierung. de/ dateien/ffh_asb_anisus_vorticulus.pdf, accessed February 2012. 


\title{
SUMMARY
}

\section{A contribution to knowledge of freshwater molluscs (Mollusca) of the Krka River in the Krka National Park (Croatia)}

\author{
L. Beran
}

This paper presents the results of a malacological survey of the Krka River and adjacent habitats (e. g. pools) in the Krka National Park. Freshwater molluscs were studied at 14 sites between Skradinski Buk waterfalls and Knin from 2009 to 2013. Altogether 27 species of freshwater molluscs (19 gastropods, 8 bivalves) were found. The number of species found at particular site varied from 4 to 17 species. Theodoxus fluviatilis, Bithynia tentaculata, Valvata piscinalis, Stagnicola fuscus, Physa fontinalis and Anodonta anatina were dominant molluscs. The river is inhabited by both molluscs living in flowing waters and species preferring stagnant waters, due to the character of this river.

Most of the recorded molluscs belong to common species in this part of Croatia. The endangered gastropod Anisus vorticulus was found at several sites and due to the large size of this lake and the existence of suitable habitats there we can conclude that the population is the most extensive one known in the western part of Croatia belonging to the Adriatic Sea drainage area. Only one non-native gastropod (Physa acuta) was found during this research.

Results of this research were compared with molluscan assemblages of the Zrmanja River situated to the north of the Krka River. The Krka River is significantly less occupied with small hydrobiids while gastropods preferring stagnant waters are more frequent there. 